\title{
Merab Mamardashvili and his philosophical calling
}

\author{
Marina F. Bykova ${ }^{1}$
}

Published online: 6 September 2019

(c) Springer Nature B.V. 2019

Philosophy is not a profession; it is rather a temperament and a way of life. And I cannot give you a sum of knowledge, I can only pass on something very intimate....

Mamardashvili (1990, p. 338)

This special issue commemorates one of the most original Russian philosophers of the Soviet era, Merab Konstantinovich Mamardashvili (1930-1990). The Georgianborn thinker received his education and spent almost his entire philosophical career in the Russian capital, working at various institutions in Moscow, including Lomonosov State University (MGU), a number of the research institutes at the Soviet Academy of Sciences, and the country's principal philosophical journal Problems of Philosophy [Voprosy filosofii].

As a graduate student at MGU, he joined, and eventually became a key representative of an informal discussion group known as the Moscow Methodological Circle (MMC), led by Georgy Shchedrovitsky. This group, still virtually unknown in the West, was the source of many important developments in post-Stalin Soviet philosophy, rivaling the philosophical research done in the Anglophone analytic tradition.

After defending his doctoral (Ph.D.) dissertation in 1961, Mamardashvili was appointed editor of the recently organized international political journal Problemy mira $i$ sotsializma [Problems of the World and Socialism], which was based in Prague (former Czechoslovakia). While the journal—known in the West by the title of its English-language edition, World Marxist Review-had a specific communist ideological agenda, working for the periodical opened a number of great opportunities for a young thinker. His work in Prague gave him access to Western literatureboth professional and literature books-which was essentially lacking in Moscow, and it also provided him with the chance to travel in Western Europe. In addition to mastering his French and English, during these travels, he met and engaged in philosophical conversations with Jean-Paul Sartre, Louis Althusser and other European intellectuals. Mamardashvili would later recall his time in Prague as one of his most formative experiences.

Marina F. Bykova

mfbykova@ncsu.edu

1 North Carolina State University, Raleigh, USA 
However, his assignment in Prague did not last long, and in 1966, as a result of an unauthorized extension of his visit to Paris, he was summoned to return to Moscow and banned from traveling abroad for nearly two decades. During this period of "internal emigration," as Mamardashvili called it, he declared himself politically and ideologically free and began pondering his own philosophical project. His project was all about thought, a truly free thought that he viewed as an integral part of the world itself and which, he believed, similar to Descartes's cogito, could shed light on our own existence and reveal its true meaning. He would pursue this project of thinking his entire life by making his main concern true existence and how to grasp this true existence in thought. When he was once asked to comment on who he really was and what was most important for him in life, Mamardashvili replied: "Thinking is my way of being. ... Thinking of existence is a mode of existence of the thinker." Yet thinking for him was much more than an ability to formulate a rational thought or just a technical skill of reasoning. The thinking that he pursued was of a special kind: it requires a conscious critical reflection on one's own thinking and an ability to realize and describe this process systematically. His philosophizing is a conscious report about the progression of thinking. For him, the act of philosophizing is not only originally rooted in the event of thinking, but is reflectively identical with the very process of thinking, which has a "cosmic" quality. For him, philosophical thinking is therefore not merely a cultural but a "cosmic" phenomenon-in the sense that it becomes a necessary condition of being. Philosophizing understood in this way corresponds with the Socratic tradition, where searching for truth is in itself a way of being, i.e. of living in and through truth.

For his unswerving desire for truth and unique methods of philosophizing, Mamardashvili was dubbed "the Georgian Socrates." Like the Athenian Socrates, he was both admired and despised: loved by those who favored intellectual independence and envied by those who represented dogmatic values. By resisting the existing Soviet ideology, he was a "constant nuisance to established order" (Van der Zweerde 2006, p. 199). At the same time, his genuine adherence to free thought made him a role model for the Soviet intelligentsia during the 1970s-1980s.

During his lifetime he managed to write a few significant monographs (Mamardashvili 1968, 1984), though most of his works are collections of his interviews, lectures, and talks (Mamardashvili 1982, 1990). A brilliant orator, he turned his standing-room-only lectures into public thought performances. His few publications and numerous lectures placed him outside official Soviet philosophy. Though trained in the tradition of Marxism and dialectical materialism, he was never sympathetic towards dogmatic Marxist philosophy and orthodox thinking, and although many of his topics echoed those of Marx, his own reading of Marx remained free of any philosophical dogmatism and obscurantism. It was a unique situation for philosophical culture in Soviet Russia, where only a few philosophers succeeded in being independent—both intellectually and institutionally_from the official ideology of dogmatic Marxism.

Fearlessly maintaining his intellectual independence-often in discord with Soviet ideology - he had taken on the study of consciousness, its symbolic (and linguistic) structures and forms of manifestation in real life, thereby contributing to philosophy of mind, metaphysics, and political philosophy. Interested in 
consciousness and working on such questions as how it perceives, shapes, and can be mistaken about reality, he formulated insights about its role in social being. For him consciousness is not just a natural human ability; it evolves and manifests itself in the metaphysical space of language and human cooperation (Mamardashvili 1978). While pursuing the rationalist theory of perception, he analyzed and compared phenomenological and Kantian paradigms for understanding thought (Mamardashvili 1968, 1984).

His philosophy of literature (especially his reading of Marcel Proust) allowed him to search passionately for the truth of Being and existence. Acting upon this truth was his philosophical and personal calling. His posthumous lectures (Mamardashvili 1991; Mamardashvili 1993, 1995, 2000) are perhaps the most significant in his textual heritage. Due to the Soviet politics of Iron Curtain as well as the delay in publication of Mamardashvili's textual legacy, only recently have scholars been able to explore his philosophical project.

Mamardashvili's philosophy is very rich, yet accessible to anyone who is willing to enter and explore the world of his ideas. It is very intimate and personal and reaches beyond the traditional philosophical themes and conventional responses to most fundamental questions of thinking and being. While it is believed that a philosophical inquiry begins with wonder, for Mamardashvili, philosophy is associated with effort and risk. Those are the conditions that make his philosophical discourse possible. His original and thought provoking contributions to philosophy continue to intrigue a broad audience of students of philosophy and other intellectuals. The present issue of Studies in East European Thought introduces only a few discussions of some of his central philosophical ideas, offering an opportunity to learn more about contemporary Mamardashvili scholarship.

\section{References}

Mamadashvili, M. K. (2000). Aesthetics of thinking [Estetika myshleniya]. Moscow: Moskovskaya shkola politicheskikh issledovanii.

Mamardashvili, M. K. (1968). Forms and content of thinking [Formy i soderzhanie myshleniia]. Moscow: Vysshaia shkola.

Mamardashvili, M. K. (1978). Arrow of cognition. An outline of natural-historical epistemology [Strela poznaniia. Nabrosok estesstvenno-istoricheskoi gnoseologii]. Moscow: Sckola.

Mamardashvili, M. K. (1984). Classical and nonclassical ideals of rationality ([Klassicheskii $i$ neklassicheskii idealy ratsional'nosti]. Moscow: Azbuka.

Mamardashvili, M. K. (1990). How I understand philosophy [Kak ia ponimaiu filosofiiu]. Moscow: Progress.

Mamardashvili, M. K. (1991). Kantian variations [Kantianskie variatsii], ed. by Yu.P. Senokosov. Moscow: Agraf.

Mamardashvili, M. K. (1993). Cartesian meditations [Kartezianskie razmyshleniia], ed. by Yu.P. Senokosov. Moscow: Progress - Kul'tura.

Mamardashvili, M. K. (1995). Lectures on Proust. (Psychological topology of the way) [Lektsii o Pruste (Psikhologicheskaya topologiya puti)], ed. by E. Oznobkina, I.K. Mamardashvili, and Yu.P. Senokosov. Moscow: Ad Marginem. 
Mamardashvili, M. K., \& Piatigorsky, A. (1982). Symbol and consciousness. Metaphysical discussions on consciousness, symbolism, and language [Simvol i soznanie. Metaphizicheskie rassuzhdeniia o soznanii, simvolikei iazyke]. Moscow: Shkola "Yazyki russkoi kul'tury.

Van der Zweerde, E. (2006). Philosophy in the act: The socio-political relevance of Mamardašvili's philosophizing. Studies in East European Thought, 58(3), 179-203.

Publisher's Note Springer Nature remains neutral with regard to jurisdictional claims in published maps and institutional affiliations. 